(Reprinted from Nature New Biology, Vol. 236, No. 61, pp. 5-7, March 1, 1972)

\title{
Translation of Two Messenger RNAs from Lens in a Cell Free System from Krebs III Ascites Cells
}

SPECIALIZED tissues which synthesize only a small number of different proteins offer obvious advantages as sources of specific and pure messenger RNAs (mRNAs). Presumptive mRNAs have been isolated and partially characterized from reticulocytes $^{1,2}$, muscle ${ }^{3}$, myelomas ${ }^{4}$ and eye lens ${ }^{5}$. The messenger role of 9S RNA from reticulocytes has been established by its ability to direct the synthesis of haemoglobin in cell-free systems from reticulocytes ${ }^{2}$ and Krebs II ascites tumour cells ${ }^{6}$, and in Xenopus oocytes ${ }^{7}$. We show here that $10 S$ and 14S RNA fractions from calf lens direct the synthesis of different polypeptide components of lens crystallin in the ascites cell-free system. These results complement and extend the demonstration, in the accompanying article ${ }^{8}$, that $14 S$ lens RNA is translated in the reticulocyte lysate. 


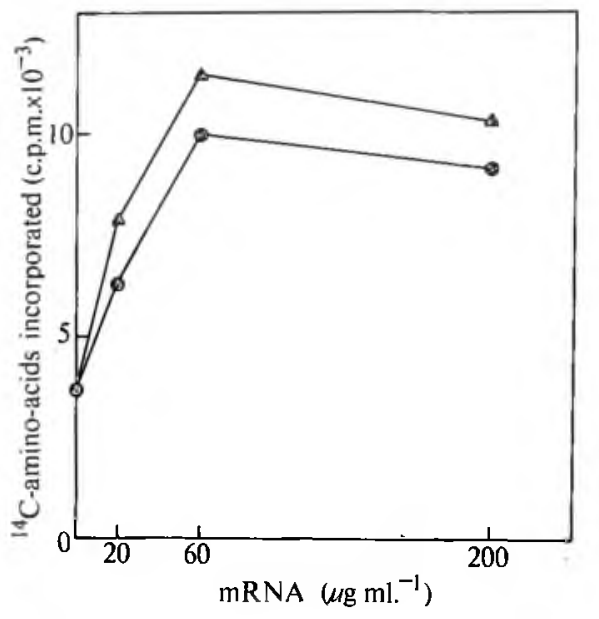

Fig. 1 Stimulation of protein synthesis by lens mRNAs. Reactions contained in $25 \mu 1$. : $10 \mu \mathrm{l}$. preincubated ascites S-30, $2.5 \mathrm{mM} \mathrm{Mg}$ acetate, $100 \mathrm{mM}$ KCl, $25 \mathrm{mM}$ Tris- $\mathrm{HCl}$ (pH 7.5), $6 \mathrm{mM}$ 2-mercaptoethanol, $1 \mathrm{mM}$ ATP, $0.1 \mathrm{mM}$ GTP, $5 \mathrm{mM}$ creatine phosphate, creatine phosphokinase $\left(0.2 \mathrm{mg} \mathrm{ml} .^{-1}\right)$ and $5 \mu \mathrm{Ci} \mathrm{ml} .^{-1}$ of a mixture of ${ }^{14} \mathrm{C}$-labelled amino-acids (54 $\mathrm{mCi}$ matom $^{-1}$, Radiochemical Centre, Amersham) supplemented with the six missing amino-acids (asparagine, cysteine, glutamine, histidine, methionine and tryptophan), at $20 \mu \mathrm{M}$ each. Lens mRNA was added as indicated. After incubation at $37^{\circ} \mathrm{C}$ for $60 \mathrm{~min}$, incorporation into hot TCA precipitable material was assayed as before ${ }^{9}$. $\triangle, 10 \mathrm{~S}$ mRNA;, $14 \mathrm{~S}$ mRNA.

Messenger RNA fractions were isolated by zonal centrifugation through a sucrose gradient of lens polysomes dissociated by sodium dodecylsulphate (SDS) ${ }^{5}$. Ascites S-30 was prepared and preincubated as described previously ${ }^{9}$, and conditions for protein synthesis were those used for translation of globin $\mathrm{mRNA}^{6}$. In contrast to the non-preincubated reticulocyte system in which total incorporation is reduced by added mRNA, ${ }^{2,8}$ the ascites $S-30$ was stimulated by $10 S$ or 14S lens RNA (Fig. 1). As with globin mRNA, the lens messengers are translated about once on average. The products have been identified by co-electrophoresis with added marker crystallins both on SDS gels, which separate polypeptides according to molecular weight ${ }^{10,11}$, and on acidic and basic urea gels which separate according to charge. 


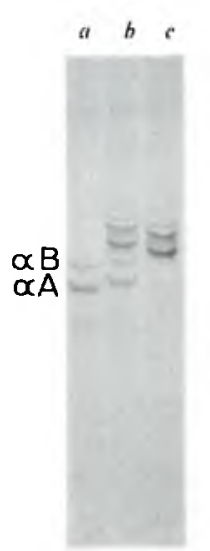

$\alpha \alpha+\beta \beta$

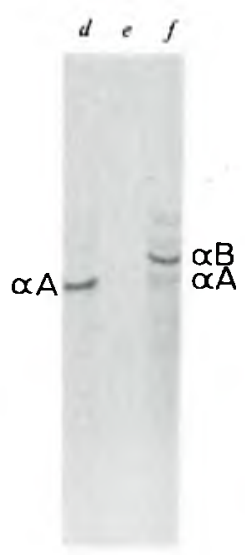

RNA: $14 S$ O 10 S

${ }^{14} \mathrm{C}$-Amino-acids

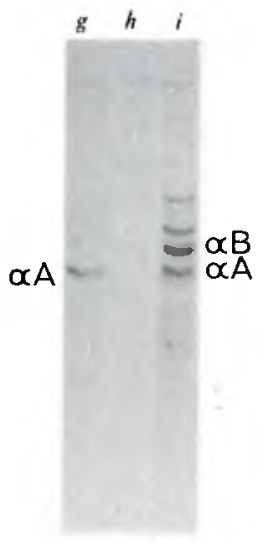

RNA: 14S 0 10S

${ }^{35}$ S-Methionine

Fig. 2 SDS gel analysis of the cell-free product. Protein synthesis reactions ( $50 \mu 1$.$) , performed as in Fig. 1, used either$ ${ }^{14} \mathrm{C}$-amino-acid mixture (see Fig. 1), or ${ }^{35} \mathrm{~S}$-methionine $(10 \mu \mathrm{M}$, $10 \mathrm{Ci} \mathrm{mmol}^{-1}$ ) plus the remaining nineteen unlabelled aminoacids $\left(20 \mu \mathrm{M}\right.$ each). Lens mRNA was added at $60 \mu \mathrm{g} \mathrm{ml} .^{-1}$ where shown. After $60 \mathrm{~min}$ at $37^{\circ} \mathrm{C}$ reactions were terminated by incubation for $15 \mathrm{~min}$ at $37^{\circ} \mathrm{C}$ with pancreatic RNase (20 $\mu \mathrm{g} \mathrm{ml}^{-5}$ ) and $10 \mathrm{mM}$ EDTA. SDS and 2-mercaptoethanol were added to $2 \%$ and $1 \%$ respectively, together with 5-10 $\mu \mathrm{g}$ of unlabelled $\alpha$ or $\beta$ crystallin markers, and the entire reaction mixture was heated to $100^{\circ} \mathrm{C}$ for $2 \mathrm{~min}$. Gels contained $0.1 \%$ SDS, $15 \%$ acrylamide and $0.4 \%$ methylenebisacrylamide, and were $9 \mathrm{~cm}$ long. A stacking gel was used, and gels were prepared and run as in ref. 26, except that the ionic strength of the running buffer was doubled. The gels were stained and destained $^{11}$, and longitudinal slices were dried before autoradiography. SDS gels of 5-10 $\mu \mathrm{g}$ of $\alpha, \alpha+\beta$ and $\beta$ crystallins respectively, stained with Coomassie brilliant blue are shown in $a-c$. Autoradiographs (4 days) of ${ }^{14} \mathrm{C}$-labelled cell-free product with added 14S mRNA, 10S mRNA and no added mRNA are shown in $d, f$ and $e$ respectively. Autoradiographs of ${ }^{35} \mathrm{~S}$-methionine labelled cell-free product with added 14S mRNA, 10S mRNA and no mRNA are shown in $g, i$ and $h$ respectively. The labels $\alpha \mathrm{A}$ and $\alpha \mathrm{B}$ on the autoradiographs indicate that the labelled bands were exactly superimposable on the stained bands of added $\alpha$ crystallin marker which were clearly distinguishable against the background of the proteins of the ascites cell-free system.

Water soluble lens proteins can be fractionated into $\alpha, \beta$ and $\gamma$ crystallins, each containing several polypeptide species $^{12-14}$. SDS gel electrophoresis of purified $\alpha$ crystallin reveals two fractions, $\alpha A$ and $\alpha B$, with apparent molecular 


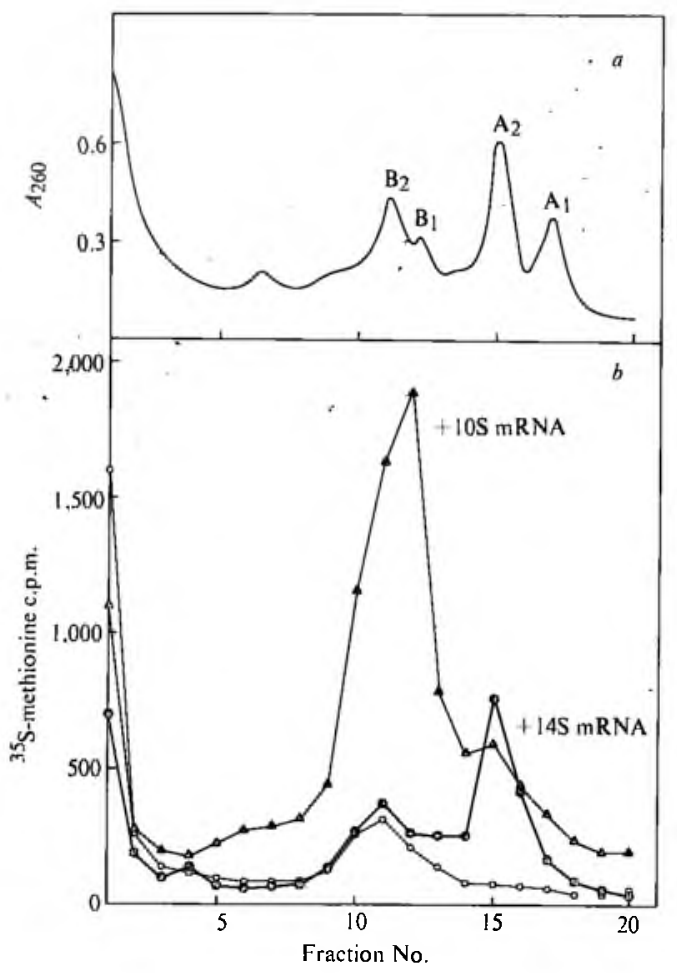

Fig. 3 Analysis of cell-free product on alkaline urea gels. Protein synthesis reactions $(20 \mu 1$.$) , and RNAase treatment were$ carried out as in Fig. 2. The proteins were then precipitated with $5 \%$ TCA and washed (5\% TCA twice, ethanol, ethanol : ether $(1: 1)$, and ether once each). The labelled sample together with $100 \mu \mathrm{g} \alpha$ crystallin was applied to polyacrylamide gels containing $6 \mathrm{M}$ urea ( $p \mathrm{H} \mathrm{8.9)}$ and electrophoresed as previously described. Subsequently the gels were stained with amido black, monitored for absorbance at $540 \mathrm{~nm}$ and cut into $1.5 \mathrm{~mm}$ slices which were solubilized in NCS and assayed for radioactivity by scintillation counting.

weights of 19,000 and 22,000 , present in the ratio of $2: 1$ (Fig. $2 a$ and refs. 15 and 16 ). Similarly, $\beta$ crystallin contains several polypeptides with molecular weights between 23,000 and 27,000 (Fig. $2 c$ ). When $\alpha$ and $\beta$ crystallins are run together the individual polypeptide chains can be resolved clearly (Fig. 2b). 
The products of cell-free protein synthesis were mixed with either unlabelled $\alpha$ or $\beta$ crystallin and electrophoresed on SDS gels, which were subsequently stained for protein, sliced longitudinally and dried for autoradiography. The polypeptide chains of the added crystallin marker were clearly identifiable on the stained gels against the background of ascites cell proteins. Autoradiographs of endogenous and mRNA-stimulated products are shown in Fig. $2 d-i$. The endogenous ascites products, labelled with either ${ }^{35} \mathrm{~S}$-methionine (Fig. $2 h$ ) or ${ }^{14} \mathrm{C}$-amino-acid mixture (Fig. $2 e$ ) in the absence of added mRNA, showed no radioactive bands in the crystallin region. In contrast, the cell-free product made with added 14S mRNA exhibited a single radioactive band which corresponded exactly with unlabelled crystallin $\alpha \mathrm{A}$ marker (molecular weight 19,000 ). This was so when either ${ }^{35} \mathrm{~S}$-methionine (Fig. $2 g$ ) or ${ }^{14} \mathrm{C}$-amino-acid mixture was used (Fig. $2 d$ ), and there was little contamination with other radioactive products.

The 10S mRNA directed the synthesis of material migrating with crystallin $\alpha \mathrm{B}$ (molecular weight 22,000 ), and lesser amounts of material which migrated with crystallin $\alpha \mathrm{A}$ and with $\beta$ (or possibly $\gamma$ ) chäins (Fig. $2 f,{ }^{14} \mathrm{C}$-amino-acid mixture). The apparent proportions of $\beta$ and $\gamma$ crystallins in the 10S mRNA product is exaggerated when ${ }^{35} \mathrm{~S}$-methionine is used (Fig. 2i), presumably because of their higher content of this amino-acid ${ }^{13}$. Furthermore, comparison of Fig. $2 d$ and Fig. $2 g$ shows that this label leads to an underestimate of the amount of crystallin $\alpha \mathrm{A}$ synthesized under the direction of 14S mRNA relative to the amount of $\alpha \mathrm{B}$ in the 10S product. This is unexpected as the methionine contents of $\alpha \mathrm{A}$ and $\alpha \mathrm{B}$ crystallins are similar ${ }^{17}$.

Gels run in urea at $p \mathrm{H} 3.0$ (in the absence of SDS) which separate the $\mathrm{A}$ and $\mathrm{B}$ chains of $\alpha$ crystallin $^{16}$ support these conclusions but do not allow further identification of the cellfree products. Urea gels run at $p \mathrm{H} 8.9$ (in the absence of SDS) provide further identification, since the $\alpha \mathrm{A}$ and $\alpha \mathrm{B}$ fractions are resolved into two components each, namely $\alpha \mathrm{A}_{1}, \alpha \mathrm{A}_{2}$, $\alpha B_{1}$ and $\alpha B_{2}$ (Fig. $3 a$ and refs. 8 and 18). The ${ }^{35}$ S-methionine labelled cell-free products gave the profiles shown in Fig. $3 b$. The 14S mRNA gave rise almost exclusively to crystallin $\alpha A_{2}$, which may be a precursor of $\alpha A_{1}$ (ref. 19). The 10S mRNA product seems to contain both $\alpha \mathrm{B}_{2}$ and $\alpha \mathrm{B}_{1}$, though unequivocal identifications cannot be made because some $\beta$ crystallins also migrate in this position (Herbrik and Bloemendal, unpublished results).

These results indicate that the two lens mRNAs are active in the Krëbs II ascites cell system and direct the synthesis of at least two identifiable lens polypeptide chains. It is surprising that the mRNA coding for crystallin $\alpha \mathrm{A}_{2}$ (molecular 
weight 19,000 ) sediments as rapidly as $14 \mathrm{~S}$. By contrast the messengers for globin (molecular weight 16,000 ) and crystallin $\alpha B$ (molecular weight 22,000 ) sediment at $9 S^{1,2}$ and $10 S^{5}$ respectively. This disparity might be explained in several ways. (1) The sedimentation coefficient of the $14 \mathrm{~S} \mathrm{mRNA}$ might be anomalously high giving a spurious estimate of its molecular weight. Measurements of the sizes of the RNAs in denaturing conditions do not support this possibility. (2) The $14 \mathrm{~S} \mathrm{mRNA}$ might contain very long untranslated regions. Untranslated regions exist in bacteriophage RNA $^{20}$ and mammalian mRNA ${ }^{21-23}$. The low proportion of adenylate residues in lens $\mathrm{mRNA}^{5}$ makes it unlikely that A-rich sequences are responsible. (3) The 14S RNA might be bicistronic, coding for two polypeptide chains. (4) The initial product might be a longer precursor molecule which is proteolytically trimmed to yield crystallin $\alpha$ A. Such posttranslational modification has a precedent in the processing of virus coded proteins in picornavirus-infected cells ${ }^{25}$.

The lens mRNAs are translated in the Krebs II ascites cell system with no requirement for additional lens components. Similarly lens ${ }^{8}$ and myeloma ${ }^{4}$ mRNAs have been translated in the reticulocyte cell-free system, and globin mRNA in Xenopus oocytes ${ }^{7}$ and in cell-free extracts from Krebs $\mathrm{II}^{6}$ and Landschutz ascites cells, and rat and mouse liver (manuscript in preparation). These results suggest that neither tissuespecific nor species-specific initiation factors are obligatory, at least in these instances.

Finally, this work, and our work with globin mRNA ${ }^{6}$, show that the ascites system combined with SDS gel electrophoresis gives a rapid and sensitive assay for messenger activity.

This work was supported in part by the Netherlands Foundation for Chemical Research and the Netherlands Organization for the Advancement of Pure Research. M. B. M. is a Beit Memorial Research Fellow.

Michael B. Mathews MARY OSBORN

MRC Laboratory of Molecular Biology, Hills Road, Cambridge

Department of Biochemistry, ANTON J. M. BERNS HANS BLOEMENDAL

University of Nijmegen, Nijmegen

Received November 12; revised December 6, 1971. 
1 Chantrenne, H., Burny, A., and Marbaix, G., Prog. Nucleic Acid Res. Mol. Biol., 7, 173 (1967).

2 Lockhard, R., and Lingrel, J. B., Biochem. Biophys. Res. Commun., 37, 204 (1969).

${ }^{3}$ Heywood, S. M., and Nwagwu, M., Biochemistry, 8, 3839 (1969).

4 Stavnezer, J., and Huang, R. C. C., Nature New Biology, 230, 172 (1971).

5 Berns, A. J. M., de Abreu, R. A., van Kraaikamp, M., Beneditti, E. L., and Bloemendal, H., FEBS Lett., 18, 159 (1971).

6 Mathews, M. B., Osborn, M., and Lingrel, J. B., Nature New Biology, 233, 206 (1971).

7 Lane, C. D., Marbaix, G., and Gurdon, J. B., J. Mol. Biol., 61, 73 (1971).

8 Berns, A. J. M., Strous, G. J. A. M., and Bloemendal, H., Nature New Biology, 236, 7 (1972).

9 Mathews, M. B., and Korner, A., Europ. J. Biochem., 17, 339 (1970).

10 Shapiro, A. L., Vinuela, E., and Maizel, J. V., Biochem. Biophys. Res. Commun., 28, 815 (1967).

11 Weber, K., and Osborn, M., J. Biol. Chem., 244, 4406 (1969).

12 Bloemendal, H., Bont, W. S., Jongkind, J. F., and Wisse, J. H., Exp. Eye Res., 1, 300 (1962).

13 Bjork, I., Exp. Eye Res., 3, 254 (1964).

14 Bjork, I., Exp. Eye Res., 3, 248 (1964).

15 Spector, A., Li, L. K. Augusteyn, R. C. Schneider, A., and Freund, T., Biochem. J., 124, 337 (1971).

16 Schoenmakers, J. G. G., Matze, R., van Poppel, M., and Bloemendal, H., Intern. J. Protein Res., 1, 1 (1969).

17 Schoenmakers, J. G. G., and Bloemendal, H., Biochem. Biophys. Res. Commun., 31, 257 (1968).

18 Schoenmakers, J. G. G., and Bloemendal, H., Nature, 220, 790 (1968).

19 Palmer, W. G., and Papaconstantinou, J., Proc. US Nat. Acad. Sci., 64, 404 (1969).

20 Sanger, F., Biochem. J., 124, 833 (1971).

21 Edmonds, M., Vaugham, M. H., and Nakazato, H., Proc. US Nat. Acad. Sci., 68, 1336 (1971).

22 Lee, S. E., Mendecki, J., and Brawerman, G., Proc. US Nat. Acad. Sci., 68, 1331 (1971).

23 Burr, H., and Lingrel, J. B., Nature New Biology, 233, 41 (1971).

24 Lim, L., and Canellakis, E. S., Nature, 227, 710 (1970).

25 Baltimore, D., in The Biochemistry of Viruses (edit. by Levy, H. S.), 101 (Dekker, New York, 1969).

26 Laemmli, U. K., Nature, 227, 680 (1970). 